\title{
Florestan Fernandes
}




\title{
Florestan Fernandes revisited
}

\author{
BARBARA FREITAG
}

\section{Introduction}

LORESTAN FERNANDES's inclusion in the "Interpreters of Brazil"
Conference Cycle, which was idealized by the Brazilian Academy of
Letters, took place due to the merit of this great sociologist from São Paulo who, according to the literary critic Antonio Candido (2001), is one of the greatest sociologists in Brazil; and possibly one of the greatest in the world as well. The conference date was unintentionally set by the organizers of the cycle; nevertheless, it became a symbolic one for, on July 22, 2005, Fernandes would have celebrated his $85^{\text {th }}$ birthday. Additionally, on August 10, 2005, we will remember the $10^{\text {th }}$ anniversary of his death.

In this text, a summary of Florestan Fernandes's trajectory will be presented in the form of a biography or a mini-résumé (cf. Freitag, 1969, $1985,1995,1998)$. Subsequently, the first phase of the author's works - from 1941 to 1968 — will be discussed. In the beginning of 1969, the sociologist was deprived of his chair at the Sociology Department of the University of São Paulo (USP) by means of a "compulsory retirement" imposed by the regime established with the 1964 military coup d'état and the decree of the Institutional Act Number 5 in 1968. His second production phase (from 1970 to 1986) will then be commented. This phase corresponds to the works produced during his exile in Canada and his seclusion in Brazil, in which he endured, according to his own words, "a downfall process of his relationship with the intellectual world." In a third phase, which begins with his entrance to the Workers' Party (Partido dos Trabalhadores, PT) in 1986, his works as a federal deputy and member of the Constituent Assembly will be commented. Finally, as a provisional conclusion, there will be a comparison among the "academic-scientist" of the first phase, the "revolutionary-politician" of the second one, and the "lonely militant" (and member of the Workers' Party - a "petista") of the third one. In this comparison we will search for a dialectical synthesis of the several facets of Fernandes's personality as an "intellectual”, classifying him together with other intellectuals of Heinrich Heine, Jean-Paul Sartre, and Jürgen Habermas's stirps, among others.

\section{Florestan Fernandes's life course}

By revisiting the author's works I am also recalling his very especial life course: the son of a Portuguese washerwoman who, according to some biographers, was an illiterate, Fernandes had a tough and laborious childhood. 


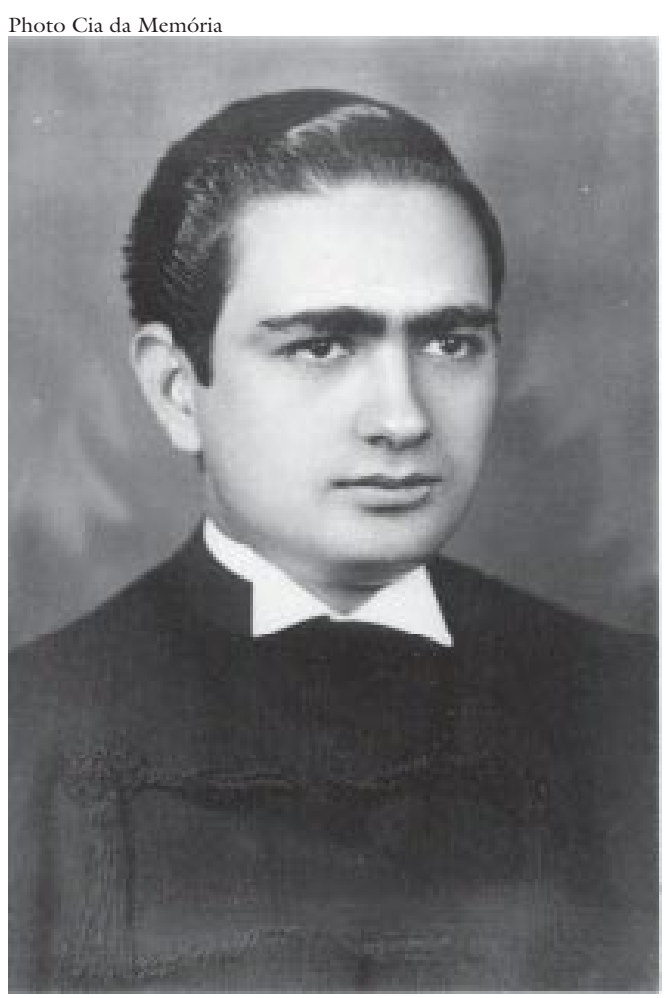

Florestan Fernandes, at the age of 23, when he got his degree from the School of Philosophy, Letters and Human Sciences of the University of São Paulo - 1943.
He attended only three years of primary education in São Paulo, as he worked as a shoe shiner, waiter's assistant, delivery boy, and had to take a series of other odd-jobs. In the end of the 1930's, he took the maturity exam $^{\mathrm{a}}$ and, in 1941, he started studying social sciences (anthropology and sociology) at the University of São Paulo (USP). Among his professors were Roger Bastide, Emílio Willems, Radcliff-Brown and Donald Pierson. He graduated in 1945 and was offered a job as an assistant professor of the chair of sociology at USP, which was then occupied by Roger Bastide. In 1964 he became a full professor and, through a nomination of his master, he took over the chair. Five years later, he was dismissed from the position as an imposition of the military Institutional Act Number 5, being compulsorily retired. Fernando Henrique Cardoso, Otávio Ianni and many other of his colleagues of USP and of other Brazilian public universities had the same destiny. At the time, Florestan Fernandes was 45 years old and was halted at the top of his intellectual and academic career. In the beginning of the 1970's, he accepted an invitation from the University of Toronto, in Canada, where he eventually became a full professor. He came back to Brazil in 1973 for personal reasons. Being forbidden to teach by the military regime, he coordinated the series "Great Social Scientists" at Editora Ática, and strived to earn a living as he could. He had previously refused invitations to work in the United States, in Germany and even at Cebrap, an institution founded with the financial support of Fundação Ford by the banned social scientists - among whom were his former students Fernando Henrique Cardoso, Arthur Gianotti and José de Souza Martins. He had political reasons for doing so: he wouldn't work for institutions that were sponsored by US resources as he attributed the initiative of starting and supporting the military coup d'état in Brazil to the USA.

With the foundation of the Workers' Party in the 1980's, he received an invitation to join the political party from Luiz Inácio Lula da Silva himself. However, he only accepted the invitation in 1986, when Lula explained to him that the party would not finance him but, on the contrary, the sociologist would 
finance the party. In that same year he was elected deputy as a candidate of São Paulo's PT. He helped to elaborate the 1988 Constitution in Brasília and was reelected for another parliamentary term. In spite of the party's insistence, he did not run for the third time alleging health-related reasons. He died in August 1995 , a few days after celebrating his $75^{\text {th }}$ birthday. Reports say that he was a victim of medical error or hospital negligence after a liver transplantation.

\section{Visiting and revisiting Fernandes's works in three phases}

First phase - During the development of my master's dissertation (1965-1967), defended at the Social Sciences Department of Freie Universität Berlin.

I have never been a regular student of Florestan Fernandes. I started my sociology studies, at the undergraduate level, with Th. W. Adorno and Max Horkheimer in Frankfurt/M. After the retirement of these giants of thought, I moved to Berlin where I set the goal of developing, in 1965, my master's dissertation - a comparison of the works of three Brazilian social scientists: Gilberto Freyre (1900-1985), Florestan Fernandes (1920-1995) and Celso Furtado (1920-2004); focusing on their conceptions about the past, present and future of Brazilian socioeconomic development.

During the research, all three authors were still alive. I contacted them (by mail, by telephone and during their conferences in Germany and in Brazil) and, whenever possible, made appointments to meet them personally. Thus, I visited G. Freyre in Apipucos, Recife, and attended his lectures delivered at the Free University of Berlin. I visited Florestan Fernandes at his office on Maria Antônia Street, São Paulo, and looked for him at his residence on Nebrasca Street, in Brooklyn, São Paulo. I also attended to and, several times, worked as an interpreter in German-Brazilian colloquia that took place in Western Germany as well as in Berlin, with the presence of Florestan Fernandes. I got in touch with Celso Furtado, a professor of the École des Hautes Études in Paris at the time. He kindly helped me with the material and sent me books to facilitate the development of my dissertation. I only met him personally at clandestine lectures he delivered at the University of Brasília (UnB) in the beginning of the 1970's, when he responded to invitations from the economist Edmar Bacha, a colleague of mine at UnB at the time.

In my dissertation I made use of an epistemological frame provided by Karl Mannheim, which he defended in "Ideology and Utopia" (1935). According to him, the (social) scientists, independently of their original cultural and social background, belong to the freischwebende Intelligenz, that is, to the intelligentsia; they are concerned with detaching themselves from their class origins and seek to accomplish an "objective" analysis of the society in which they live. My question was whether this thesis was also valid for the selected Brazilian authors. By reading the works of the anthropologist from the Northeast of Brazil, Gilberto Freyre, I could ascertain that he was still 
deeply attached to the traditions of Colonial Brazil, whose institutions latifundia, (sugar) monoculture, and slavery - he described in such a brilliant way in his book "The Masters and the Slaves" (1933). By defending the thesis of the inexistence of racial prejudice in Brazil, he idealized the relationship between the masters and the slaves and revealed the ideological bias of a man who belonged to the rural elites of the sugar cycle.

Interested in finding out whether Freyre's diagnosis was accurate, Unesco put Roger Bastide in charge of developing a broader study in the South of Brazil in more recent years (those of the coffee plantations). The French anthropologist invited Florestan Fernandes to be his research partner who, in turn, included Fernando Henrique Cardoso and Otávio Ianni in the broad research project on the life conditions of African descendants in Republican Brazil. All the studies indicated the same trend: from Colonial Brazil up to the present day, relationships of oppression, hierarchy and exploitation (of both labor and sexuality) of whites over blacks have been predominant. The ideology of the Brazilian racial democracy cultivated by Freyre and his followers concealed a conflict between races and classes, which Florestan Fernandes denounced in his wide research about "The Integration of Blacks into Class Society” (1966).

According to Fernandes, early $20^{\text {th }}$ century Brazil was filled with contradictions and "dilemmas". Among them, he pointed a "social dilemma" of a rural, estamental society in process of modernization that could not free itself from the ghosts and structures of the past. The slave mentality (despite the abolition of slavery in 1888), the substitution of (immigrants') free manual labor for field manual labor, and the latifundium structure based on coffee monoculture and exports made it unviable for the imposed industrialization to keep the accumulation standards required to implement a "competitive social order". The "patrimonial society" lacked agents that could represent the entrepreneurial rationality and spirit, which was, in his point-of-view, a requisite for the implementation of capitalism in Brazil. The lack of modernization's dynamizing agents retarded the introduction of new technologies, transportation systems, banking systems, as well as base structures of a new competitive order. The installation of such order, namely the class structure and its conflict regulation mechanisms, lingered; and it was never able to completely extinguish the old patrimonial order from the mentality and actions of the social actors inserted in the democratic State, in the political party system and in the schools. Thus, social ascension mechanisms worked more as "obstacles" than as agents of change.

For Fernandes, the "racial dilemma" lay in the fact that the abolition of slavery happened in a rash way (1888) that did not provide the free black people with a real integration into white society. Excluded from the labor market and deprived of a professional education and of experience in the free (competitive) labor market, former slaves would necessarily be marginalized 
from the on-going inclusion and modernization processes, from which only the (Japanese, Italian, German, Polish) immigrants would benefit in the long run. In the above mentioned work, "The Integration of Blacks into Class Society" (1966), Fernandes exposes, in a dramatic manner, the way in which exclusion mechanisms worked for the black man. The Swedish economist Gunnar Myrdal called these mechanisms "processes of circular and cumulative causation". The lack of professional education reduced the job opportunities for the black man, descendant of slaves. Having no dignified job or adequate remuneration, he was thrown into an anomie process (social and psychic disorganization and disintegration, in Durkheim's terms), which, in turn, hindered his access to social ascension mechanisms such as school education, democratic vote, and accomplishment through work.

The "educational dilemma" also expresses - in Fernandes's first phase reflections - an ambiguity of the Brazilian societarian system that officially describes itself as democratic and postulates education as a social ascension and inclusion mechanism. However, it is actually very selective and little attractive to the underprivileged ones (blacks, poor, women and other minorities).

These three dilemmas would explain why early $20^{\text {th }}$ century Brazilian society apparently did not have racial conflicts or discrimination. There is actually an overlap of class and race in which socioeconomic differences and injustices conceal racial conflicts. Poor people were mostly black or multiracial. Poverty outshines race. At school (even at public ones) and universities, black and multiracial people are under-represented; most of the vacancies are filled by whites.

In studies about indigenous people, blacks and whites in Brazil, especially in regard to their educational opportunities, Fernandes does not hide his unconditional sympathy and solidarity towards the oppressed, excluded or underprivileged people. Far from being "unattached" to his social origins, as Mannheim would state, Fernandes uses them as a weapon to reveal the cynicism and the ideology of a hypocritical society that defines itself as democratic, but actually accumulates privileges to traditionally benefitted minorities. Thus, it reinforces injustices that are crystallized in one of the most elevated income concentrations in the world.

In the conclusion of my dissertation, defended in 1967, I confronted a paradox. On the one hand, Fernandes would make use of a positivistic sociology, with theories based on Durkheim, Weber, Radcliff Brown, Mannheim and Hans Freyer, which are essentially "academic" and "conservative". On the other hand, our author has proven himself to be a critical and politically engaged social scientist that vehemently defended a political cause in the "Campaign for the Defense of the Public School" (1962), which was concerned with the oppressed, excluded and marginalized. This parted him from the scientist's neutrality demanded by positivism.

In my master's dissertation, I also compared Fernandes's position with that of Celso Furtado, born in 1920 in Paraíba, actively engaged in enhancing 
life conditions of poor people in the Northeast. Since this author will be dealt with by Hélio Jaguaribe, I will restrict my observations to the results exposed in my dissertation. Similarly, Celso Furtado never met the demands of the German sociologist Max Weber of separating scientific from political vocation. Analyzing and transforming Brazilian reality constituted, both for Fernandes and Furtado, two sides of the same coin.

In Celso Furtado's case, similarly to Fernandes's, the Mannheimian conception of the intellectual "above all" who is objective and free-floating, unattached to immediate class interests, has proven itself to be a chimera. Once and for all, Mannheim's epistemological framework, to which Fernandes intended to adhere, was not able to impose itself in any of the three cases that have been analyzed.

Oversimplifying it, my study seemed to confirm the Marxist thesis that our Weltanschaunng (worldview) is a reflex of the material conditions in which we live. Das Sein bestimmt das Bewusstsein, that is, "being determines consciousness".

Thus, Freyre's studies on Brazilian reality reflected his insertion in Colonial Brazil as a descendant of the sugar master class, whereas Fernandes's reality of blacks and whites in Brazil during the coffee cycle showed his deep connection to the black and immigrant cultures. Finally, Celso Furtado, the son of the Northeast backlands, an organic intellectual of the developmental state, engages himself in a project - namely Cepal - to overcome the poverty, drought and decadence of his motherland. Nonetheless, he was brought down (with the 1964 coup d'état) by the old oligarchies of that same region (Castelo Branco).

Second phase - Florestan Fernandes One-Day Conference in Marilia, dedicated to the great social scientists (organized by Unesp in 1986).

When I was invited by the organizers of "Florestan Fernandes OneDay Conference", which took place at Unesp's campus in Marilia in 1986, twenty years after the defense of my dissertation, I accepted to speak in the part dedicated to the issues of "University and Democracy", debating "Democratization, University, and Revolution" in Florestan Fernandes's works. In these twenty years both of us had returned to Brazil and were (re)starting a professional career that had been interrupted by along period abroad (Fernandes had been in Canada and I had been in Germany). While Fernandes had returned to São Paulo, I started (with his help) my academic career at UnB, Brasília (1972). In the first years back in Brazil, my job as a professor kept me away from Fernandes's production of articles and books. I systematically started revisiting his works after the invitation to participate in the conference in his honor.

After reading his most recent work and getting in touch with his late writings (after his return to São Paulo, 1968-1986), I defended the thesis of an "epistemological break" in Fernandes's works, comparable to the one indicated 
by Althusser in Marx's works. My argument was that Fernandes's intellectual production undergoes, at the turn of the 1960's to the 1970's, a profound reorientation. In order to punctuate this change, I christened his early works, prior to the break, as his "academic-reformist" phase; and the period after the Institutional Act Number 5 as "political-revolutionary" (which corresponds to the above mentioned first and second phases of production).

The break would be characterized by the fact that Fernandes made use, in his first phase, of a basic theoretical concept primarily based on Durkheim, Weber, Mannheim, Freyer and Radcliff Brown (among others) and a functionalist methodology focused on problematics classified under three different themes:

(a) debate and reflection on sociology as a discipline;

(b) anthropological analysis of the Brazilian indigenous peoples;

(c) detailed studies of Brazilian reality.

In the second phase, which I named "political-revolutionary" (in the 1970's), Fernandes would have changed his theoretical concepts, basing his analysis on Marx, Engels and Lenin's concepts, on the method of historical materialism, and on authors of the Marxist school. His problematics also changed, focusing on the analysis of

(a) urban guerrilla;

(b) Cuban revolution;

(c) Brazilian (and South-American) military dictatorship.

In the first phase, which I called "academic-reformist", Fernandes's work is a reflex (with regard to the sociological theoretical reflection) of the following titles: "Essays on General and Applied Sociology", 1960; "Sociology in an Era of Social Revolution", 1963; and "Empirical Foundation of Sociological Explanation", 1965.

In these works, which are quite academic, the author expresses the conviction that a real scientific sociology, practiced seriously and understood as a real "theoretical work" (see, among others, Fernando Henrique Cardoso's testimony in Angela D'Incao's collection “Militant Knowledge”, 1987), would be able to function as a propeller of deep transformations in society and as a tool of awareness and mobilization of organized social forces.

The theme of the anthropological analysis of the Brazilian indian was dealt with in: "Social Function of War in Tupinambá Society", 1952 (doctoral thesis); "Ethnology and Sociology in Brazil", 1958; and "Folklore and Social Change in the City of São Paulo", 1961, among others.

Here, Fernandes tried to demonstrate that an academic methodology, the anthropological "functionalism", was able to reconstruct the structure of a society even if it was already on the verge of extinction.

Finally, the first phase publications on Brazilian reality are focused on the themes I approached in my master's dissertation, namely: the "social dilemma", the "black dilemma", and the "educational dilemma". I will bring 
up only a few of the main titles: "Social Change in Brazil", 1961; "Blacks in White Society", 1961, published with Roger Bastide; "The Integration of Blacks into Class Society", 1965 (habilitation thesis); and "Education and Society in Brazil", 1966.

Let us observe the themes and issues he approached in the second phase, in which, according to my terminology, one can see the manifestation of the "political-revolutionary" Fernandes. These are the works published after the 1964 military coup d'état and, especially, after the decree of the Institutional Act Number 5, which parted Fernandes from the academic life at the University of São Paulo, when he was at the top of his career, and obliged him to restart his life and analyze Brazilian reality from the very beginning: "The Bourgeois Revolution", 1975, "From Guerilla to Socialism: the Cuban Revolution", 1975, "Challenging the Dictatorship", 1983, "New Republic?", 1985.

At this point, I emphasized the fact that Fernandes not only changes his conceptual and theoretical benchmark, using Marx and Lenin's historical materialism, but he also becomes less "scientific" and more polemic, political and revolutionary. Fernandes realized, by actually experiencing it, that not even the person who is highly aware and skilled at creating accurate diagnosis of their own time has the power of transforming society as an isolated individual. Their potential of transforming global reality depends on international conjunctures and trends, in which the single individual is submerged, deprived of any intervention and transformation power. When using concepts such as "capitalist mode of production", "imperialism", "relations of production", he is aware of the fact that these are historical phenomena that take place independently of personal wills and slide as an avalanche über die Köpfe der Individuen hinweg (Marx), "over our heads".

In my lecture, however, I presented the following qualification (1986):

This epistemological break certainly did not take place from one day to another, like his compulsory retirement did after the establishment of the Institutional Act Number 5, in 1968. In the reformist Fernandes lay the embryo of the revolutionary Fernandes. But the latter might not have developed in such a radical and consistent way towards socialism had the political conjuncture been different, that is, had the populist-developmental pact been kept on. Some traces of the embryonic presence of the revolutionary in the reformist could be found specially in themes and issues he selected and studied thoroughly such as the contradictions inherent to Brazilian society, latent racial conflicts, $[\ldots]$ educational dilemmas $[\ldots]$ (p. 168).

In order to confirm my break thesis, I made use of the collection of texts written during the academic reformist's first phase ("Education and Society in Brazil", 1966) and of texts of the second phase - the political revolutionary one ("Brazilian University: Reform or Revolution?", 1975, and texts such as "USP's Issues” and "USP: Past and Present”, both from 1984). 
Confronting the texts of the first phase with those of the second, reformist Fernandes's bet on the use of education, science, and specially university as decisive tools for the social reconstruction of Brazilian society. The education in general and higher education, in this version, would work as a real lever to achieve successful social change, according to Karl Mannheim's models (cf. "Freedom and Social Planning", 1945).

In the works of the second phase (the revolutionary one), in turn, Fernandes argues that, for a new university to exist, one should not act only in the realm of a university reform, but also in the realm of revolutionary action. Such action was supposed to start not by changing the university but by the revolution itself. It also had to take place in the society as a whole, so that the changes in the university could be successfully accomplished. In his own words: "the issue of Brazilian university [in 1984, at the celebration of USP's fiftieth anniversary] is inserted in a global revolutionary movement and will be solved with the emergence of the working class in the Brazilian historical scenario" (cf. quoted by Freitag, 1987, p. 177).

Third phase - Florestan Fernandes as a member of the Workers' Party and of the Constituent Assembly.

In my efforts to revisit Fernandes's works, I emphasized the production of a first phase (from 1941 to 1969), which I named "academic-reformist", and of a second phase (from 1970 to 1986), in which I pointed out a radicalization of the theoretical and political jargon of this great Brazilian sociologist. In 1986, when the author joins the Workers' Party and is elected federal deputy, this second phase is closed.

A new phase, the third one, was starting in Fernandes's intellectual life. As from that moment, in which the new deputy would walk around the corridors of the National Congress and work in diverse plenary sessions at the Chamber of Deputies, I could only follow his TV appearances sporadically but I read his articles in Folha de S. Paulo and received the printed transcripts of his speeches at the Chamber regularly.

In the beginning of the 1990's, I agreed to orient the master's dissertation about Fernandes of a former student of mine, in which she intended to systematize his performance as a politician, examine his newspaper articles and his speeches at the Chamber. Additionally, she proposed to realize a series of interviews with the deputy in Brasília that were to be completed by interviews with Antonio Candido, Fernando Henrique Cardoso, Ruth Cardoso, and Arthur Gianotti. Eliane Veras was able to record twelve interviews from 1990 to 1992, which helped her to reconstruct Fernandes's itinerary, from his childhood to his job at the National Congress in Brasília. She also consulted the letters I exchanged with the sociologist approximately 30 years ago, as well as text and photograph files assembled by Fernandes's friends and admirers. In this context, Tarso Venceslau's interview with Fernandes, published in the journal Debate e Critica, also has great importance. 


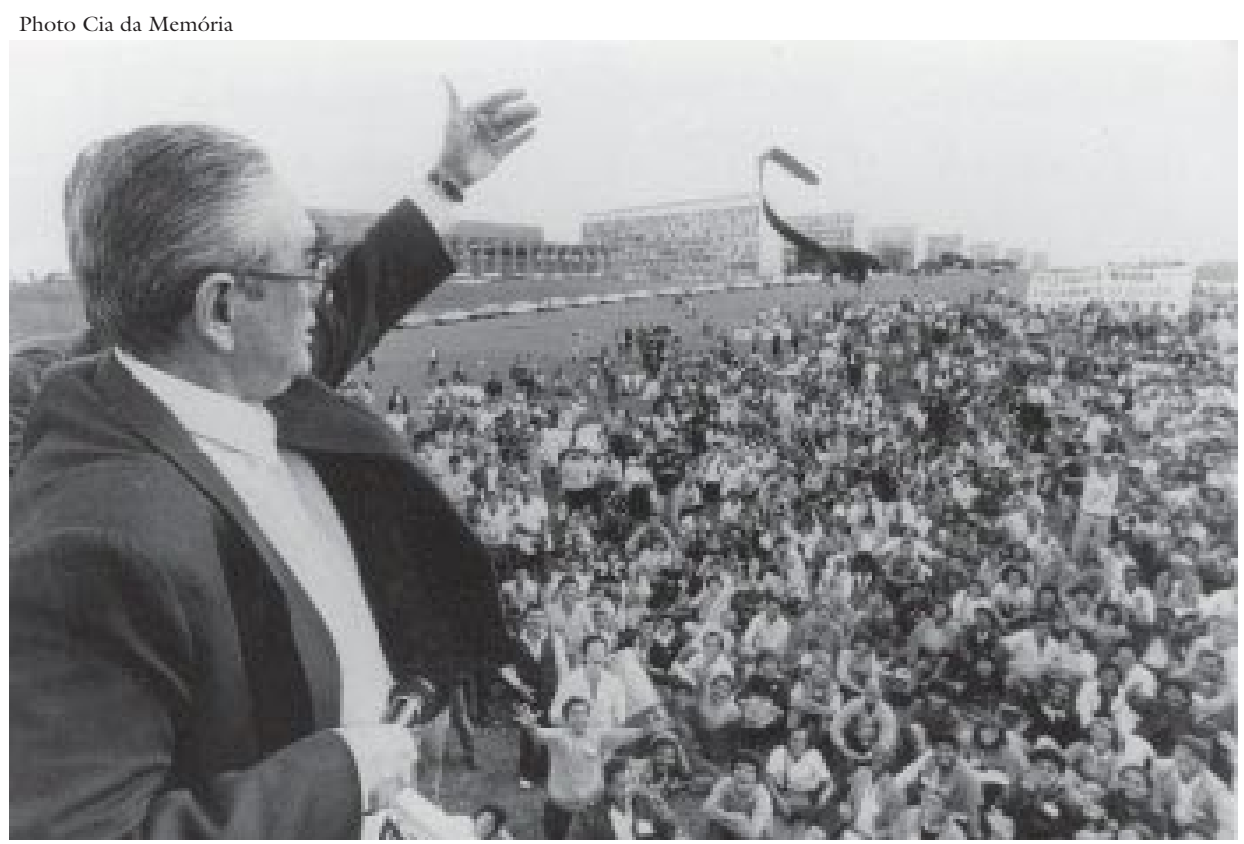

Florestan Fernandes in a manifestation in front of the National Congress during the 1988 Constituent Assembly.

In an effort to reconstruct Fernandes's life course and political trajectory, Eliane Veras's thesis explains several aspects of his life, which, according to each different report, took on folk or distorted forms. It became clear that Fernandes had never been part of the Communist Party or of the Brazilian Communist Party (PCdoB) due to the patrolling and authoritarianism of their members, which our author did not accept. This fact has been confirmed by Antonio Candido in several testimonies. The simple fact that Fernandes had read Marxist texts and had brought to Brazil (with the assistance of the existent English and French translations) Marx's "A Contribution to the Critique of Political Economy" did not make him a Marxist. In the diverse testimonies and in Fernandes's letters, it is clear that the so-mentioned "epistemological break" started a few years before the decree of Institutional Act Number 5, namely in 1964, the year in which the military coup d'état against João Goulart's government took place. Nevertheless, curiously enough, these facts, which were external to the Brazilian repressive policies, did not lead to an analysis methodological and conceptual change. In 1964, Gianotti, Fernando Henrique Cardoso, Otávio Ianni and Robert Schwartz created a Reading Group on Marx and they invited their former master to participate in it. Fernandes, however, turned the invitation down, though he was conscious he would have to refeed his theoretical readings and analyze Brazilian reality through a more adequate conceptual in order to understand the 1964 coup d'état and the several institutional acts of the military government. On that occasion, Fernandes turned to a "lonely militant" pathway. His trip to Canada provided him with an opportunity of 
a theoretical "recycling", without falling into a "vulgar Marxism", like many others at the time. Florestan Fernandes has never given in to idiosyncrasies, including the French Marxism advocated by the group Lire le Capital, to which Poulantzas, Rancière, Establet and Balibar belonged; focused on Gramsci and Machiochi who became a real fever in France and in Brazil but did not affect Fernandes.

After his return to Brazil, in 1973, Fernandes got back to his works on the analysis of the "Bourgeois revolution", which had been initiated before the coup d'état, interrupted because of his trip to Canada and, finally, concluded in 1974. At this point, the theoretical and methodological reorientation (which I named "cut") becomes evident. In this dense text, interrupted for more than 6 years, our author tries (with great difficulty) to resume the patrimonial order analysis of colonial origin and "explain" how, starting from the analysis and in spite of it, the "competitive social order", that is, the capitalist society, could be implemented (in the Brazilian Southeast region).

In his third production phase (already as a member of the Workers' Party and of the Chamber), Fernandes would never work at an institution of higher education again. His conversations and letters displayed the contempt he felt for the bureaucratization of the university and for the egocentric carreerism of most of the professors and researchers, who would also pass these attitudes on to the newer generations. The years during which he believed he could change Brazilian society using a deep scientific understanding of the reality and with the help of science, education and planning (categories lent to Mannheim) were gone for good.

The involvement with the political party (namely the Workers' Party, PT) and with the Democratic State, as he worked at the subcommissions of the Constituent Assembly (Education), was what he had left.

[In the Chamber] I was able to see how the economical, cultural, and juridical elites work as well as the military elites, deputies and senators, which are those predominantly chosen in these sectors. Therefore, I got to know the Brazilian society better, especially the processes through which the concentration of power, the concentration of wealth and culture are kept in such a fierce way [...] (cf. Veras, pp. 117-118).

A similar paradox takes place in relation to his performance as a political articulator at Folba de S. Paulo. Actually, Fernandes does not seek to form political opinions and awareness only. Indeed, he tries to "educate" his reader, considering journalism a more effective tool than a teacher in the classroom. Inside and outside the Congress in Brasília, he was known as the "master of masters".

\section{Provisional conclusion}

By revisiting Fernandes's three phases in life, which also comprise three significant moments in his works, I tried to rebuilt and piece together 
parts of a puzzle that would give us a trustworthy image of the character and work of one of the greatest interpreters of Brazil. In search of a "common denominator" in all of his production phases, I believe I found a suggestion in the metaphor of the "three houses" used by his daughter Heloísa Fernandes. According to this metaphor, Florestan Fernandes would have effectively worked in the construction of the houses of knowledge, of socialism, and of his rural origins. I, therefore, wonder: why do we not build a single house, in a sole plan, comprising all of Fernades's efforts to adequately "interpret" Brazilian society? Keeping ourselves faithful to his daughter's metaphor, we would only have to put a roof on top of all of his periods of life and production, gathering them to form a mansion. In this mansion, each of his facets - the academic and scientist, indicated by Souza Martins (1986), the reformist and revolutionary, highlighted in my thesis of the "epistemological break" presented in Marília, and the "political socialist" detailed in Eliane Veras's work on the "lonely militant" - would have its own place.

I believe I found, in Habermas, a solution to the dilemma we all face when trying to understand, frame and label Fernandes. He was simply one of the greatest intellectuals Brazil has ever seen. But this concretization will only be valid if we accept the concept of the intellectual characterized by Habermas, setting the concept of freisch-webende Intelligenz aside, a concept coined by Mannheim that marked my first works and those of Fernandes himself as well.

The intellectual may be characterized, among other features, by the fact that he/she did not resign any elitist dimension and that he/she speaks, in the public space, not as a party supporter intellectual, or as a counselor to the king, but on his/her own behalf, as a citizen who, naturally, has the goal of convincing the others (cf. Jürgen Habermas in "Habermas: 70 Years”, 1998).

According to this concept, which sees the intellectual as a critical man inserted in his own time and in problems and issues of every-day life, we could gather the different facets of Florestan Fernandes's works, discussed in the three phases of his life and work as a researcher, a revolutionary and a lonely militant.

\section{Note}

1 This maturity exam was designed to enable access to the university to candidates who had not followed the orthodox school curriculum.

\section{Bibliography}

CANDIDO, Antonio. Florestan Fernandes. São Paulo, Fundação Perseu Abramo, 2001.

FERNANDES, Florestan. Textos políticos. Câmara dos Deputados, Brasília, 1985-1995. "O processo constituinte: pronunciamentos e debates". 1988. 
FERNANDES, Florestan. “A Constituição inacabada: vias históricas e significado”. 1989. . "Pensamento e ação: O PT e os rumos do Socialismo". 1989.

. “A transição prolongada: o período pós-constitucional”. 1990.

"Parlamentarismo: contexto e perspectivas". 1992.

. "Democracia e desenvolvimento: a transformação da periferia e o capitalismo monopolista atual". 1994.

. “A contestação necessária”. 1995.

. "Em busca do socialismo: últimos textos \& outros contextos". 1995.

FREITAG, Barbara. Habermas: 70 anos. Rio de Janeiro, Tempo Brasileiro, 1998.

Número comemorativo em homenagem aos 70 anos de Jürgen Habermas.

. Florestan Fernandes: die sozio-ökonomische Entwicklung Brasiliens aus der Sicht eines brasilianischen Sozialwissenschaftlers. Saarbrücken, SSIP-Verlag, 1969.

. "Democratização, universidade, revolução". Em D'INCAO, Maria Angela

(org.). O saber militante: Ensaios sobre Florestan Fernandes. São Paulo/ Rio de Janeiro, Unesp/ Paz e Terra, 1987.

. "Florestan Fernandes: 'Ein militanter Einzelgänger'”. In SCHULTZ, Manfred (org.). Entwicklung - Empirie - Soziologie. Festschrift für Volker Lühr. Berlin, Spektrum $45,1997$.

. (ed.). "Florestan Fernandes por ele mesmo". Uma troca de cartas de Florestan Fernandes com Barbara Freitag de trinta anos (1965-1994). In Estudos Avançados 26, São Paulo, 1996.

MARTINS, José de Souza. Florestan - sociologia e consciência social no Brasil. São Paulo, Edusp, 1998.

VERAS, Eliane. Florestan Fernandes: o militante solitário. São Paulo, Cortez, 1997.

ABSTRACT - The author describes Florestan Fernandes's intellectual biography in three phases. The first phase, which she calls the "scientific-academic" stage, covers the period from 1941 to 1968 . The second phase, the "political-revolutionary" stage, corresponds to the years from 1970 to 1986. Finally, the third phase is what she calls the "lonely militant" stage (1986-1995), in which all facets of Fernandes's itinerary come together under the heading of the "intellectual", in Jürgen Habermas's definition.

KEYWORDS - Sociological Theory, Social Sciences Methodology, Social Classes.

Barbara Freitag is full professor of the Sociology Department of the University of Brasília (UnB) and university lecturer (PD) at the University of Berlin, Germany. @ - bfreitag@uol.com.br.

Translated by Cecília Mattos. The original in Portuguese is available at http://www. scielo.br/scielo.php?script=sci_issuetoc\&pid=0103-401420050003\&lng=pt\&nrm=iso.

Received on 7.26.05 and accepted on 8.3.05. 